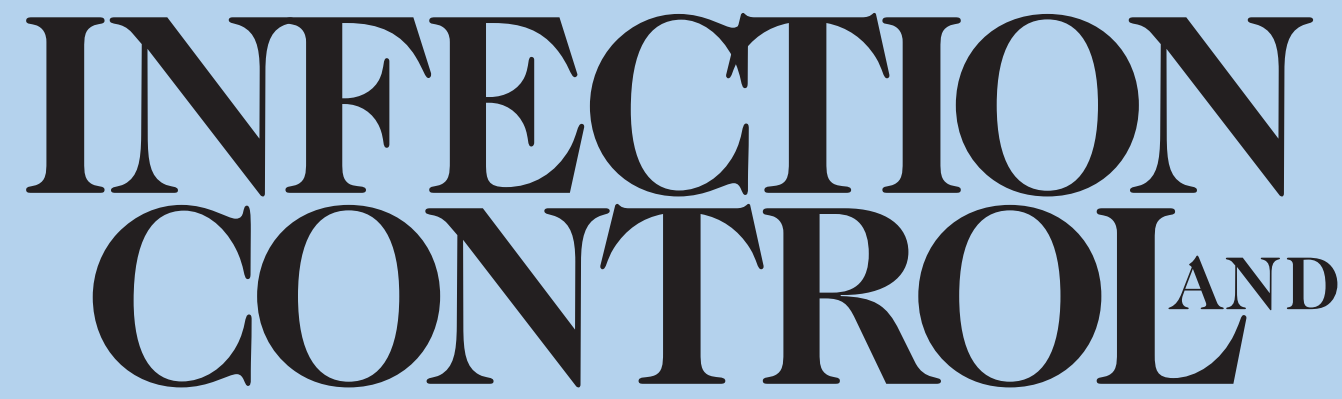

\title{
HOSPITAL EPIDEMIOLOGY
}

Volume 11, Number $9 \bullet$ September 1990

\section{EDITORIAL}

Small Round Structured Viruses: An Important 457 Infection Control Problem?

Philip C. Johnson, MD

\section{ORIGINAL ARTICLES}

An Outbreak of Acute Gastroenteritis Caused 459 by a Small Round Structured Virus in a Geriatric Convalescent Facility

George A. Gellert, MDCM, MPH, MPA;

Stephen H. Waterman, MD, MPH;

Donald Ewert, MPH; Lyndon Oshiro, MD;

Marjorie P. Giles, MA; Stephen S. Monroe, PhD;

Leo Gorelkin, MD; Roger I. Glass, MD

Adoption of Guidelines for Universal

Precautions and Body Substance Isolation in

Canadian Acute-Care Hospitals

David Birnbaum, MPH; Michael Schulzer, MD, PhD;

Richard G. Mathias, MD; Michael Kelly, MD, PhD;

Anthony W. Chow, MD

Influenza Outbreaks in Nursing Homes: How Effective is Influenza Vaccine in the Institutionalized Elderly?

Matthew L. Cartter, MD; Philip O. Renzullo, MPH;

Steven D. Helgerson, MD; Stanley M. Martin, MS;

James F. Jekel, MD

Frequent Acquisition of Multiple Strains of

Methicillin-Resistant Staphylococcus aureus by

Healthcare Workers in an Endemic Hospital

Environment

Steven M. Opal, MD; Kenneth H. Mayer, MD;

Marjorie J. Stenberg, MS; Julia E. Blazek, PhD;

Dennis J. Mikolich, MD; David L. Dickensheets, MD;

Lisa W. Lyhte, BS; Ronald R. Trudel, MS;

James M. Musser, MD, PhD 465

CLINICAL PHARMACOLOGY OF ANTIBIOTICS

Aztreonam

Allan R. Tunkel, MD, PhD;

W. Michael Scheld, MD

TOPICS IN CLINICAL MICROBIOLOGY

Strongyloides stercoralis

Deborah J. Zygmunt, MD

LETTERS TO THE EDITOR

Medical Congress in Africa

Giuliana Gialdroni, MD; Carlo Grassi, MD

Mupirocin Ointment Indications

Ian Hudson, MBBS, MRCP

BOOK REVIEW

Safety Guide for Health Care Institutions

(Fourth edition) Linda F. Chaff

Reviewed by David W. Drummond, PhD, CIH

473

SHEA NEWSLETTER

The Official Journal of The Society of Hospital Epidemiologists of America 


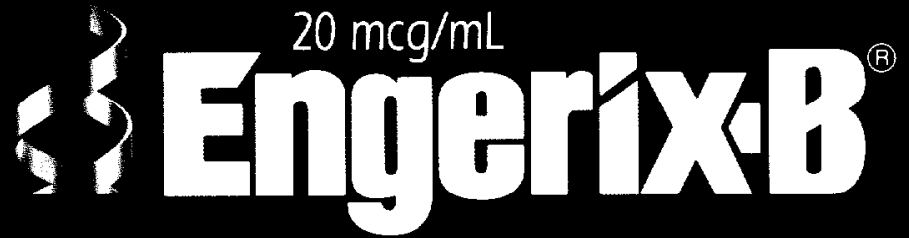 \\ Hepatitis B Vaccine (Recombinant)}

Choice of dosing regimens

Alternate 0,1,2 month dosing regimen for certain populations*

20 mcg recombinant dose

Helps to ensure immune response in adult patients of all ages

Engerix-B ${ }^{\circledR}$

Recombivax $\mathrm{HB}^{\circledR}$

\begin{tabular}{|lcc|}
\hline Adult dose (mcg) & 20 & 10 \\
\hline $\begin{array}{l}\text { Standard dosing regimen } \\
\text { (0,1 and 6 months) }\end{array}$ & $\checkmark$ & $\checkmark$ \\
\hline $\begin{array}{l}\text { Alternate 0, 1,2 month dosing regimen } \\
\text { for certain populations* }\end{array}$ & $\checkmark$ & $\checkmark$ \\
\hline $\begin{array}{l}\text { Published efficacy data: } \\
\text { Neonates born of infected mothers }\end{array}$ & $\checkmark$ & \\
\hline $\begin{array}{l}\text { VACTRAC TM_computer software for } \\
\text { vaccination tracking and compliance }\end{array}$ & $\checkmark$ & \\
\hline Bar-coded, unit-dose vials & $\checkmark$ & \\
\hline Lowest cost per dose & $\checkmark$ \\
\hline
\end{tabular}

* For those recently exposed to the virus (including needlestick exposure), certain travelers to high-risk areas and neonates born of infected mothers. When prolonged maintenance of protective antibody titers is desired, a booster dose at month 12 is recommended. 


\section{Lowest Cost Per Dose}

\section{Extensively tested and well tolerated}

State-of-the-art recombinant technology

14 million doses distributed in over 87 countries $^{3}$

\section{Switch to Engerix-B}

Can be used to complete a course of vaccination initiated with another hepatitis B vaccine ${ }^{34}$

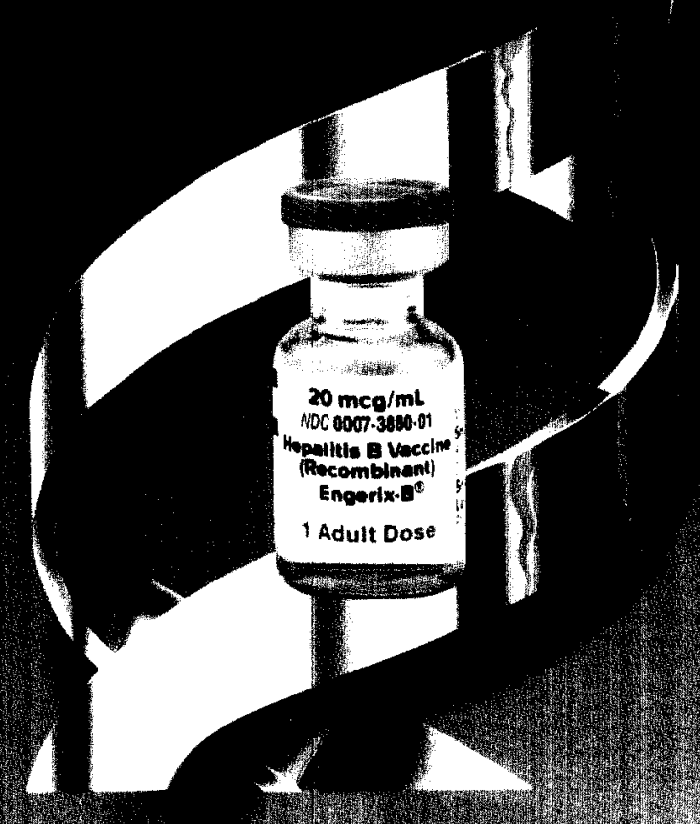




\section{Engerix-B ${ }^{\circledast}$}

Hepatitis B Vaccine (Recombinant)

See complete prescribing Information In SKeF literature or PDA. The following is a briel summary.

INOHCגTIONS AND USAGE: 'Engerix. $B$ ' is indicaled for immunization against inlection caused by all known subtypes of hepabtis B virus Immuni zation is recommended persons of all ages, especially those who ane. or will be, at increased risk of exposure to hepalitis $B$ virus

CONTRAMOICATIONS: Hypersensitivity to yeast of any other component of the vaccme is a contraindication for use of the vaccine.

WMRwimes: Do n o t gue additional injections to patients experiencing hypersensitvity alter an 'Engerix-B' injection (See CONTRANDICATIONS)

Hepatitis B has a long incubation period Hepatitis B vaccination mav not prevenl hepattitis $B$ intection in individuals who had an unrecognized hepatilts vent intection in individuals who do not achieve proteclive antibody titers.

PAECAUTIONS: General: As with any percutaneous vaccme, keep ep nephrine available for use in case ol anaphylaxis or anaphylactoid reaclion. As with any vaccme, delay administration, if possible. in persons with any febrile illness or active intection

Pregnancy: Pregnancy Category C Animal reproduction studies have not been conducted with Engenx. B It IS also not known whether Engerix $B$ B can cause leta har whe 'Edmins

Nuraing Mothers: It is not known whether 'Engerix-B' Is excreted in human milk Because many druqs are excreted in human milk, use caution when giving 'Engerix. B' to a nursing woman

Podiatric Uu: 'Engerix- $B$ ' has been shown to be well tolerated and highly immunogenic in intants and children of att ages. Newborns also resoond welt, maternally transferred antibodies do not intertere with the active immune response to the vaccme

AOVERSE REACTIONS: 'Engerix. B' is gener ally well tolerated During clini cal studies involving over 10,000 individuals distributed over all age groups no sellous adverse reactions attributable to vaccine administration we

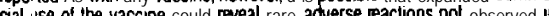
clinical studies.
clenter

Ten double-blind studies involving 2,252 subjects showed no significan difference in the frequency or severity of adverse experiences between 'Engerix- $B$ and plasma-derived vaccines In 36 clinical studies a total 0 13.495 doses of 'Engerix. $B$ ' were administered to 5,071 healthy adults and children who were initialiy seronegalive lor hepattis $B$ markers. and healthy neonates All subjects were monicred for 4 days postradministration. Fe quency of adverse expenences tended to decrease with successive doses ol verse reactions were

Incidence 14 to $10 \%$ of Injections: Induration; erythema; swelling; fever $\left(>375^{\circ} \mathrm{C}\right)$, headache', diziness.

"Parent or guardian completed torms for children and neonates Neonatal checklisl did not include headache, fatigue or dizziness

Ineidence < 1\% of Injetions: Pain, pruritus; ecchwmosis; sweating: tor loms, upper respiralory tract in tisses, ausea, anoxia, abdominal pain arm shoulder of neck, arthraloia; myaloia back pan rash, urticaria: pete chiae erythema; somnolence. in somnia; irritability; agitation

Addilional adverse experiences have been reported with the commercial use ol 'Engerix. B' outside the Unted States. Those listed below are to serve as

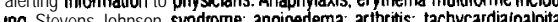
in tion tests: migraine syncope paress: neuropathy including thypesthesia ton sthesi, Gullin Barré syndrome and Bell's patsy, transverse myelitis thrombocytopenia: eczema; purpura herpes zoster vertigo conjunctivitis keralitis; visual disturbances

Polential Acverse Experiences In addition, certain other adverse expentences not observed with 'Engerix.B' have been reported with heplavax.ge+ and/o Optic neuritis

HOW SUPPUED: $20 \mathrm{mcg} / \mathrm{mL}$ in Singte Dose Vials in packages of 1.10 and 25 vials.

NDC 0007-3860.01 (package ol 1)

NDC 0007.3860 .16 (package of 25 )

$10 \mathrm{mcg} / 05 \mathrm{~mL}$ in Single-Dose Vials in packages of 1 vial

NOC 00073859.01 (package of 1)

† plasma-derived, Hepatitis B Vaccine, MSD
† yeasl-derived, Hepatitis B Vaccine, MSO.

Manutactured by SmothKfine Bcologicals, Rixensart, Belgium Distribuled by Smith Kine Efrench Laboratories

Division of Smithkline Beckman Corp. Philadelphia, PA 19101

Date of issuance Aug. 1989

BRS-EB L6

Engerix-B is a registered trademark of Smithkline Beecham

References:

1. Poovorawan Y. Sannavat S. Pongenunlert W. et al: Protective efficacy of a recombinant DNA hepatitis $B$ vaccine in neonates of HBe antigen-positive mothers. JAMA 1989. 261(22).3278-3281. 2. Based on Medi-Span Hospital Formulary Pricing Guide.

December 1989. 3. Data on fle, SKQF. 4. Bush L, Moonsantmy

G. Boscia I: Evaluption of initiating a hepatitis B vaccination

schedule with one vaccine and completing it with another.

Hepatology 1989;10:689.

\section{HATS OFF TO FIRST CLASS SERVICE}

At SLACK Inc orporated we believe our subscribers a re first class people. That's why we do everything possible to publish first class journals. And, that's why we mainta in a TOU-REE CUSTOMER SERVICE HOTUNE. For the first class customer service you deserve, call:

\section{I-800-2.57-8290}

Talk to a SLACK Customer Service Representative about:

Subsc riptions. Subsc ribing by phone is quick and easy; it only takes a minute and Visa and Mastercard are accepted.

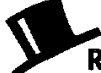

Renewals. Early subscription renewal helps a void possible interruotions in service.

Change of Address. Please notify us four weeks in advance to assure prompt del ivery to your new address.

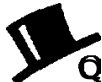

Questions or Problems. Delivery problems or questions about your subscriptions can be handled instantly.

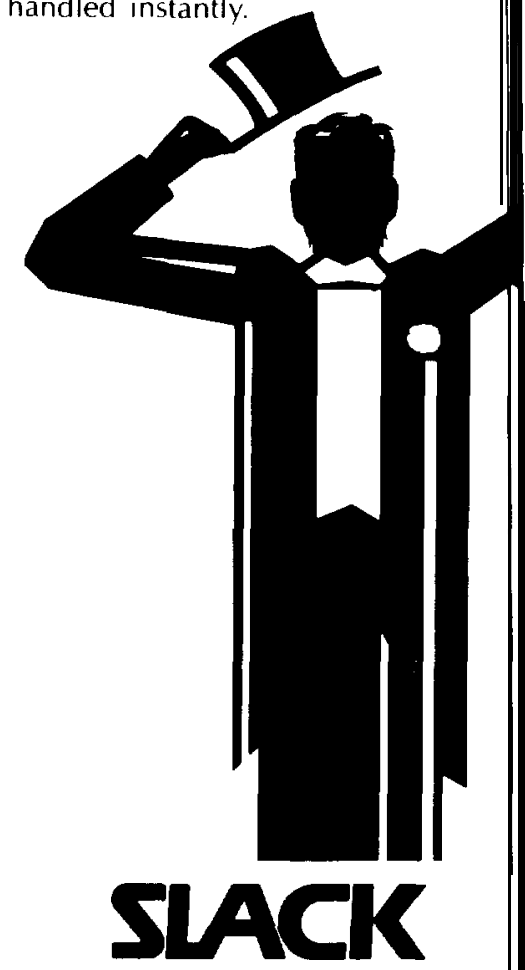

6900 Grove Road, Thorofare, NJ 08086 


\section{INFECTION CONTROL $\stackrel{\text { AND HOSPITAL }}{\text { EPIDEMIOIOGY }}$}

EDITORIAL Small Bound Structured Viruses: An Important Infection Control

Problem?

Philip C. Johnson, MD

ORIGINAL ARTICLES SPECIAL
SECTIONS

DEPARTMENTS
An Outbreak of Acute Gastroenteritis Caused by a Small Round Structured Virus in a Geriatric Convalescent Facility George A. Gellert, MDCM, MPH, MPA, Stephen H. Waterman, MD, MPH; Donald Ewert, MPH; Lyndon Oshiro, MD; Marjorie P Giles, MA; Stephen S. Monroe, PhD; Leo Gorelkin, MD; Roger I. Glass, MD

Adoption of Guidelines for Universal Precautions and Body

Substance Isolation in Canadian Acute-Care Hospitals

David Birnbaum, MPH; Michael Schulzer, MD, PhD;

Richard G. Mathias, MD; Michael Kelly, MD, PhD;

Anthony W. Chow, MD

Influenza Outbreaks in Nursing Homes: How Effective is Influenza

Vaccine in the Institutionalized Elderly?

Matthew L. Cartter, MD; Philip O. Renzullo, MPH;

Steven D. Helgerson, MD; Stanley M. Martin, MS; James F. Jekel, MD

Frequent Acquisition of Multiple Strains of Methicillin-Resistant Staphylococcus aureus by Healthcare Workers in an Endemic

Hospital Environment

Steven M. Opal, MD; Kenneth H. Mayer, MD; Marjorie J. Stenberg, MS; Julia E. Blazek, PhD; Dennis J. Mikolich, MD;

David L. Dickensheets, MD; Lisa W. Lyhte, BS; Ronald R. Trudel, MS; James M. Musser, MD, PhD

Clinical Pharmacology of Antibiotics

Aztreonam

Allan R. Tunkel, MD, PhD; W. Michael Scheld, MD

Topics in Clinical Microbiology

Strongyloides stercoralis

Deborah J. Zygmunt, MD

Information for Authors

450

SHEA Newsletter

Letters to the Editor

Calendar of Events

Book Review

498

The ideas and opinions expressed by contributing authors do not necessarily reflect those of the editors or publisher.

Publisher: Infection Control and Hospital Epidemiology (ISSN-0899-823X) Is published monthly by SLACK Incorporated, 6900 Grove Road. Thorofare, New Jersey 08086. Telephone (609) $848 \cdot 1000$

Copyright 1990: All rights reserved No part of this publication may be reproduced without written permission from the publisher.

Subscriptions: Requests should be addressed to the publisher (except Japan) In Japan, contact Woodbell Incorporated, 4-Z-11, Kitakasai, Edogawaku Tokyo 134. Japan Subscription rates in the US and possessions: Individual One year- $\$ 60$ 00; Two years - $\$ 95.00$; Three years-- $\$ 12500$ Institutional One year- $\$ 70$ 00; Two years- $\$ 11000$ Three years-- $\$ 15000$, Canada $\$ 1800$ additional each year all other countries $\$ 3000$ additional each year Singlecopies of current Issues may be obtained tor $\$ 800$. United States and possessions; $\$ 1600$ all other countries.

Reprints: All requests to reprint or use material published herein should be addressed to Lester J Fobeson. SLACK Incorporated 6900 Grove Road, Thorofare NJ 08086 For reprint orders and prices, contact Fran Micaletti at (609) 848-1000 Authorization to photocopy items for internal or personal use, or the internal or personal use of specific clients, Is granted by SLACK Incorporated, provided that the base fee of $\$ 100$ per copy plus $\$ .15$ per page IS paid directly to Copyright Clearance Center, 27 Congress Street, Salem, MA 01970 This consent does not extend to other kinds of copying, such as for general distribution, resale. advertising and promotional purposes, or for creating new collective works

Change of address: Notice should be sent to the publisher sıx weeks in advance of effective date Include old and new addresses with zip codes The publisher cannot accept responsibility for undelivered copıes Second-class postage is pad at Thorofare, New Jersey 08086. and additional entry points Postmaster: Send address changes to SLACK Incorporated, 6900 Grove Road, Thorofare, NJ 08086

As of Volume 1, Number 1, INFECTION CONTROL AND HOSPITAL EPIDEMIOLOGY is listed In Index Medicus, Current Contents - Clinical Practice, Hospital Literature Index, Cumulative Index to Nursing and Allied Health Literature, and Nursing Abstracts. 
EDITORIAL OFFICES

Vanderbilt University School of M edicine A-1131 M edical Center N orth

Nashville, TN 37232-2637

(615) 343-1095; (615) 343-1882 (FAX)

Email: iche@mcmail.vanderbilt.edu

EDITOR

M ichael D. Decker, MD, MPH

MANAGING EDITOR

Susan Cantrell

STATISTICAL EDITOR

Beverly G. M ellen, PhD

SENIOR ASSOCIATE EDITORS

C. Glen M ayhall, M D

Gina Pugliese, RN, MS

William Schaffner, M D

ASSOCIATE EDITORS

Donald A. Goldmann, M D

Didier Pittet, MD, MS

Andreas Widmer, MD, MS

SECTION EDITORS

Beyond Infection Control:

The New Hospital Epidemiology

Bryan P. Simmons, M D

Stephen B. Kritchevsky, PhD

M emphis, Tennessee

Wing Hong Seto, M D

Hong Kong

Disinfection and Sterilization

William A. Rutala, PhD, M PH

Chapel Hill, North Carolina

Emerging Infectious Diseases

Larry J. Strausbaugh, M D

Portland, Oregon

Robert W. Pinner, M D

Atlanta, Georgia

From the Laboratory

M arcus Zer vos, M D

Royal Oak, M ichigan

Fred C. Tenover, PhD

Atlanta, Georgia

Information Management

John A. Sellick, DO

Buffalo, N ew York

The International Perspective

M ary D. Nettleman, M D, MS

Richmond, Virginia

Issues in Surgery

James T. Lee, MD, PhD

St. Paul, M innesota

Medical News

Gina Pugliese, RN, M S

Chicago, Illinois

M artin S. Favero, PhD

Irvine, California

Practical Healthcare Epidemiology

Loreen A. Herwaldt, M D

lowa City, Iowa

SHEA News

M urray D. Batt, M D

Clarksburg, West Virginia

Statistics for Hospital Epidemiology

David Birnbaum, PhD, M PH

Sidney, British Columbia, Canada

Topics in Long-Term Care

Philip W. Smith, M D

Omaha, Nebraska

Topics in Occupational Medicine

David Weber, M D, M PH

Chapel Hill, North Carolina

\section{INFECTION CONTROL AND HOSPITAL EPIDEMIOLOGY \\ EDITORIAL ADVISORY BOARD}

Jacques F. Acar, MD Paris, France

J. Wesley Alexander, MD Cincinnati, Ohio Paul Arnow, M D Chicago, Illinois

Graham A.J. Ayliffe, MD Birmingham, United Kingdom Neil L. Barg, MD Yakima, Washington

Elizabeth Ann Bolyard, RN, M PH, CIC John M. Boyce, M D

Professor Dr. Ilja Braveny Charles Bryan, MD

Christian Brun-Buisson, M D

Donald $\mathrm{E}$. Craven, $\mathrm{MD}$

Sue Crow, M SN, RN, CIC

Franz Daschner, M D

Leigh G. Donowitz, MD

Charles E. Edmiston, Jr., PhD

Theodore C. Eickhoff, MD Bruce Farber, MD

Victoria J. Fraser, M D

Peter C. Fuchs, MD, PhD

Richard A. Garibaldi, MD

Velvl Greene, PhD, M PH Robert Gaynes, M D

David W. Gregory, M D

David K. Henderson, MD

Peter N.R. Heseltine, MD

Karen Hoffmann, RN, CIC, MS

$M$ arguerite $M$ CM illan Jackson, RN, PhD

Janine Jagger, M PH, PhD William R. Jar vis, M D

Douglas S. Kernodle, M D

Robert H. Latham, MD

Lewis B. Lefkowitz, MD

Hsieh-Shong Leu, M D, M Sc Jack Levy, MD

Victor Lorian, M D

Dennis G. M aki, M D

Professor Dr. Walter M arget

William J. M artone, M D

Allison M cGeer, MD

John E. M CGowan, Jr., M D

Jonathan L. M eakins, MD, DSC Raf M ertens, M D

Robert R. M uder, MD

Joseph M. M ylotte, M D, CIC Lindsay Nicolle, M D

J uhani Ojajär vi, M D

M ichael T. Osterholm, PhD, M PH

Jan Evans Patterson, M D Sindy M Paul, MD

M ichael A. Pfaller, MD

Samuel Ponce de Leon, M D, M Sc Isaam Raad, M D

M anfred L. Rotter, M D, DipBact Theodore Sacks, M D

William E. Scheckler, M D Kent Sepkowitz, M D Denis Spelman, M D

M ichael L. Tapper, M D

Clyde Thornsberry, PhD

Professor Leonid P. Titov

Timothy R. Townsend, M D

Antoni Trilla, MD, PhD

Professor Wang Shu-Qun

J. J ohn Weems, J r., M D

Robert A. Weinstein, M D

Professor Dr. W. Weuffen

Sergio B. Wey, MD Rebecca Wurtz, M D
Atlanta, Georgia

Providence, Rhode Island

M unich, Federal Republic of Germany

Columbia, South Carolina

Creteil, France

Boston, M assachusetts

Shreveport, Louisiana

Freiburg, Federal Republic of Germany

Charlottesville, Virginia

Milwaukee, Wisconsin

Denver, Colorado

$M$ anhasset, New York

St. Louis, M issouri

Black Butte, Oregon

Farmington, Connecticut

Beer Sheva, Israel

Atlanta, Georgia

Nashville, Tennessee

Bethesda, $\mathrm{M}$ aryland

Los Angeles, California

Chapel Hill, North Carolina

San Diego, California

Charlottesville, Virginia

Atlanta, Georgia

Nashville, Tennessee

Taipei, Taiwan

Brussels, Belgium

Bronx, New York

Madison, Wisconsin

M unich, Federal Republic of Germany

Bethesda, $\mathrm{M}$ aryland

Toronto, Ontario, Canada

Atlanta, Georgia

M ontreal, Quebec, Canada

Brussels, Belgium

Pittsburgh, Pennsylvania

Buffalo, N ew York

Winnepeg, $\mathrm{M}$ anitoba, Canada

Helsinki, Finland

M inneapolis, M innesota

San Antonio, Texas

Trenton, N ew Jersey

lowa City, Iowa

M exico City, M exico

Houston, Texas

Vienna, Austria

Jerusalem, Israel

$M$ adison, $W$ isconsin

New York City, New York

Prahran Victoria, Australia

New York, New York

Brentwood, Tennessee

M insk, Republic of Belarus

Millwood, Virginia

Barcelona, Spain

B eijing, People's Republic of China

Greenville, South Carolina

Chicago, Illinois

Greifswald, Federal Republic of Germany

São Paulo, Brazil

Evanston, Illinois
Nashville, Tennessee

Nashville, Tennessee

\begin{tabular}{|c|c|c|}
\hline \multicolumn{3}{|c|}{$\begin{array}{c}\text { SLACK Incorporated } \\
6900 \text { Grove Road } \\
\text { Thorofare, N ew Jersey } 08086 \\
\text { (609) } 848-1000\end{array}$} \\
\hline $\begin{array}{l}\text { Vice President/ Group Publisher } \\
\text { Richard N. Roash }\end{array}$ & $\begin{array}{l}\text { Assistant E ditor } \\
\text { Eileen C. Anderer }\end{array}$ & $\begin{array}{l}\text { Publishing Director/ Advertising } \\
\text { Wayne M cCourt }\end{array}$ \\
\hline $\begin{array}{l}\text { Publisher } \\
\text { John C. Carter }\end{array}$ & $\begin{array}{l}\text { Circulation Manager } \\
\text { Lester J. Robeson, CCCP }\end{array}$ & $\begin{array}{l}\text { Pharmaceutical Group Sales Director } \\
\text { M ichael LoPresti }\end{array}$ \\
\hline $\begin{array}{l}\text { Editorial Director } \\
\text { Jennifer Kilpatrick }\end{array}$ & $\begin{array}{l}\text { Production Director } \\
\text { Christine M alin }\end{array}$ & $\begin{array}{l}\text { Advertising Sales Representative } \\
\text { Jennine Kane }\end{array}$ \\
\hline $\begin{array}{l}\text { Production E ditor } \\
\text { Shirley P. Strunk, ELS }\end{array}$ & $\begin{array}{l}\text { Production Coordinator } \\
\text { Joanne Patterson }\end{array}$ & $\begin{array}{l}\text { Classified/ Recruitment Sales Manager } \\
\text { M ichele Burch }\end{array}$ \\
\hline
\end{tabular}




\section{Protection is our line.}

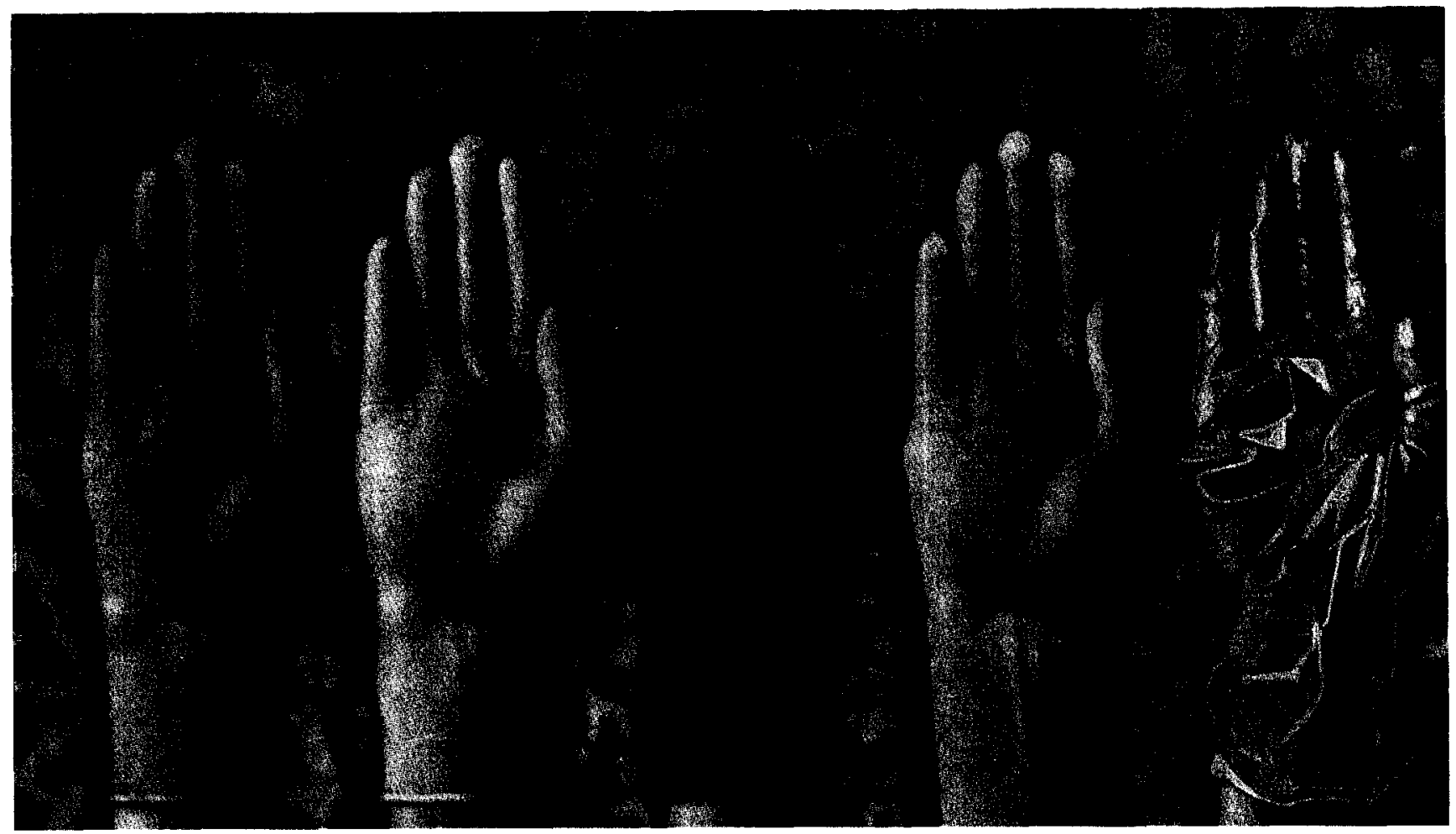

Artist interpretation of microorganisms

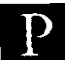

rotection. The kev to our superior glove line.

At Johnson \&Johnson Medical, Inc., we have a reputation that spans more than 20 years - years

dedicated to the research and development of quality gloves that provide maximum protection, optimum fit and excellent touch sensitivity.

We engineer quality into every aspect of our gloves beginning with 100 percent on-line visual inspection of all latex gloves, and quality standards that far exceed those recommended by the FDA.

Our protective lines include NEUTRALON" Brown Surgical Gloves, MICRO-TOUCH" Latex Surgical Gloves, MICRO-TOUCH" Latex Medical Gloves, DISPOS-A-GLOVE:" Examination Gloves and both the new MAXXUS* Orthopaedic Surgical Gloves, and the longer cuff MICRO-TOUCH'" XI' Latex Medical Gloves.

Protection and Johnson \&Johnson Medical, Inc. - an unbeatable combination.

For more information, contact your

Johnson \& Johnson Medical, Inc., Medical Specialties Sales Representative or call 1-800-433-5009.

\section{Gohusonatgohuson MEDICAL INC.}

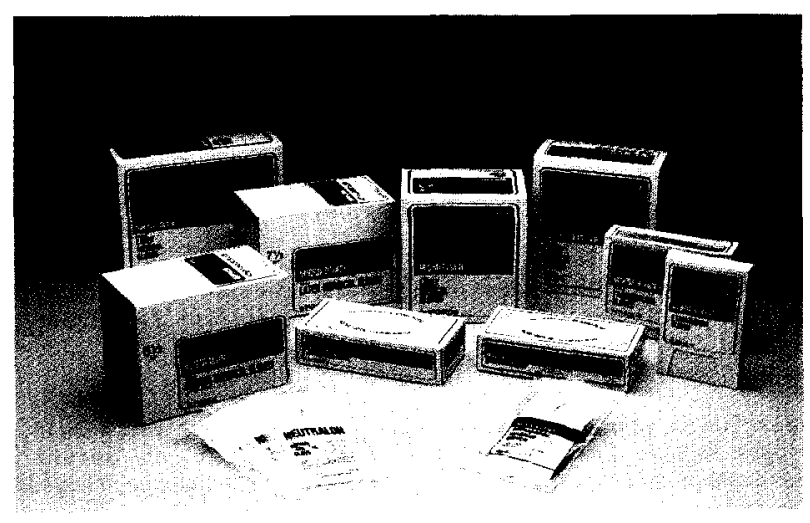

"TRADEMARK O JJM,INC. 1990 